\title{
Biotechnology and Industry 4.0: The professionals of the future
}

\author{
Gilson José da Silva', Antonio Carlos Massabni² \\ ${ }^{*}$ Corresponding author: E-mail address: gilsonphsilva@gmail.com
}

Abstract: The process of developing technological research is being carried out beyond organizational boundaries, especially organizations that make intensive use of knowledge, such as Biotechnology. Considerable progress has been made in recent years in reducing costs and increasing the ease of gene sequencing and, ultimately, in activating or editing genes. In this context, discussions have been gaining prominence around Industry 4.0, in which new business models and intelligent processes for Biotechnology are evidenced. However, the challenges regarding the training and education of professionals are discussed, emphasizing the importance of a multidisciplinary education, unlike the more traditional nature of education in the areas of biology and sciences. These challenges can be partially transposed by strengthening the partnerships of universities and research centers with companies, in order to materialize in common projects, the demands of industries and the possibilities of transforming research projects into final products available to society. This paper presents a study on the impact of Industry 4.0 technologies on Biotechnology, and also presents the prospect of future professions with the influence of Industry 4.0. The results show that technologies such as artificial intelligence, robotics and 3D printing are promising in the development and advancement of Biotechnology. New automated laboratories are under development. Also, regulatory issues require a great deal of study, and business models will need to be more efficient to generate the results needed for the development of new drugs, food, and research of new products related to health.

Keywords: Biotechnology; Industry 4.0; Industry 4.0.

\section{Introduction}

The challenges faced by current organizations have fostered the formulation of alliances and partnerships among organizations. In this context, the technological research development process is being carried out beyond the organizational boundaries, especially organizations that make intensive use of knowledge, such as Biotechnology companies. ${ }^{1}$ Also, in this context, discussions have been gaining prominence around the idea of the Fourth Industrial Revolution or Industry 4.0, in which new business models are verified, as well as accentuated remodeling in existing businesses around intelligent products, procedures and processes. $^{2}$

Great changes and innovations arise in the field of Biotechnology. Considerable progress has been made in recent years in reducing costs and increasing the ease of gene sequencing and, ultimately, in activating or editing genes. ${ }^{2}$ Advances in processing power meant that scientists no longer need to work with trial and error, making Biotechnology one of the areas that will be most impacted by advances in technology. According to the Brazilian National Confederation of Industry, Biotechnology is a disruptive technology and is intrinsically related to Industry 4.0. The introduction of new sensors, equipment and artificial intelligence applied to research ensure progress in Biotechnology; automation, big data, advanced process analysis and control and the internet of things (IoT) impact the way of work and communication in the industrial chain. ${ }^{3}$

The definition of Biotechnology is very broad. Trigueiro ${ }^{4}$ states that modern Biotechnology emerges as a complex web of technical, social, economic, political, ethical and institutional relations, demanding an effort for its development. Modern Biotechnology presents itself as an area of knowledge, encompassing different natural sciences, which transform these sciences into an object of technology.

Biotechnology has two dimensions: scientific and technological. The scientific one consists of an articulated set of basic research programs (molecular biology, biochemistry, microbiology, genetics), being developed, fundamentally, in universities and academic institutions. The technological dimension comes as the study of the means of transforming these basic researches into industrial and commercial applications. These two dimensions coexist and complement each other. ${ }^{4}$

In practice, Biotechnology is a multidisciplinary science that integrates several areas of knowledge, ${ }^{4}$ such as law and engineering, mainly chemistry, irreplaceable in the study of bioprocesses, in the pharmaceutical, food and oil industries. ${ }^{5}$ Therefore, the investment in human capital focused on the area of Biotechnology is usually considered the main determinant for the development of the field. ${ }^{6}$

However, it is still necessary to focus on and support the increase of intellectual assets involved in the front line of biotechnological research, since these are fundamental for the exploitation of the potential of manufacturing and marketing of products of biotechnological origin.

Batalha et al. discussed the challenges of capacity-building and education of professionals for modern Biotechnology in Brazil, emphasizing the importance of a multidisciplinary education, unlike the more traditional approach of education in the areas of biology and health and agricultural sciences.

These challenges can be partially transposed with the deepening of the partnerships of universities and research centers with companies, in order to materialize in common projects, the demands of industries and the possibilities of transforming research projects into final products available to society. ${ }^{6}$

The main objective of this work is to present the main impacts of Industry 4.0 in Biotechnology, the professions of the future involved in this area, and to shed light on the market perspectives and training for future professionals. Thus, it is a literature review research, using the methods of historical, analytical and deductive research, systematizing the obtained data, organizing them, to make possible, through these results, to draw specific conclusions on the proposed theme. Books, internet sites, and scientific articles located in databases such as: SciELO, Scopus, Emerald, Science Direct and Web of Science, with keywords (in Portuguese and English): Biotechnology, Industry 4.0 and future professions.

For the development of this work, first the industrial revolutions that

PhD student of the Graduate Program in Biotechnology, Regenerative Medicine and Medicinal Chemistry of University of Araraquara (Uniara).

2 Professor of the Graduate Program in Biotechnology, Regenerative Medicine and Medicinal Chemistry of University of Araraquara (Uniara). 
have transformed the labor market will be explored, after the evolution of Biotechnology and labor market. The article also discusses the impact of Industry 4.0 technologies on Biotechnology, and describes the professions of the future impacted by these technologies.

\section{Evolution of industrial revolutions}

The word "revolution" refers to the idea of radical and abrupt changes. In industry as a whole, revolutions occur when new technologies encourage profound change in the economic and social aspects of societies. ${ }^{2}$ Figure 1 shows the periods of the industrial revolution and the main technologies.

The First Industrial Revolution began with the invention of the steam engine, which made mass production possible in the 17th and 18th centuries. For example, in the textile industry, steam engines have made craftsmen's labor undervalued because the machines had greater production capacity. ${ }^{9}$

From 1811, the "Luddites" broke loom machines throughout England because they believed that this new equipment would cause mass unemployment. There was indeed a loss of employment; but the necessity of hiring unskilled labor was present, since the machines needed to be operated by the workforce. These unskilled workers who worked for a period of timebecameskilled and reached a relatively higher incomelevel. ${ }^{9}$

Countries such as the United States, Japan and England, among others, have shown that industrialization has raised their citizens to a higher standard of living. ${ }^{10}$

Over the years, technology has evolved requiring the substantial presence of a more qualified workforce, generating wealth for countries and organizations and making countries understand the factors that change the economy and the future of work. ${ }^{11}$

From the 1870s onwards, the Second Industrial Revolution occurred after a series of events, such as the use of electricity, the surge of mass production and the method of division of labor. The third revolution emerged in the early 1970s as the Digital Revolution, and was driven by the use of the first information technologies that further developed the automation of the means of production. 2,12,13

The Fourth Industrial Revolution began with the term Industry 4.0, which is derived from industrie 4.0. It was created in Germany in 2011 by the Institute Fraunhofer-Gesellschaft and the German Federal Government as a collective term that defines the set of technologies for information flow, automation and manufacturing, as a high-tech strategy for 2020.14 Politicians, universities and entrepreneurs have developed ideas to offer improvements in industrial processes involving: operation, engineering, production planning and control, logistics, and continuous analysis during the life cycle of products and..$^{15}$

Since then, the academic, scientific, business and political interest in the subject has expanded rapidly, largely due to the fact that for the first time an industrial revolution is being observed before it concretely becomes a reality. ${ }^{12}$

According to Kagermann, Wahkster and Helbig, Industry 4.0 aims to optimize industrial processes that involve manufacturing, engineering, supply chain management and the life cycle of products. Three main concepts should be considered in the implementation of Industry 4.0,
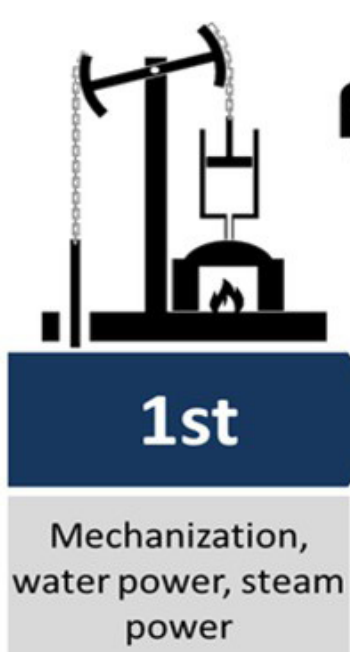

1765

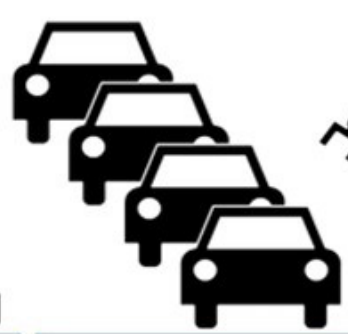

2nd

Mass production, assembly line, electricity

1870
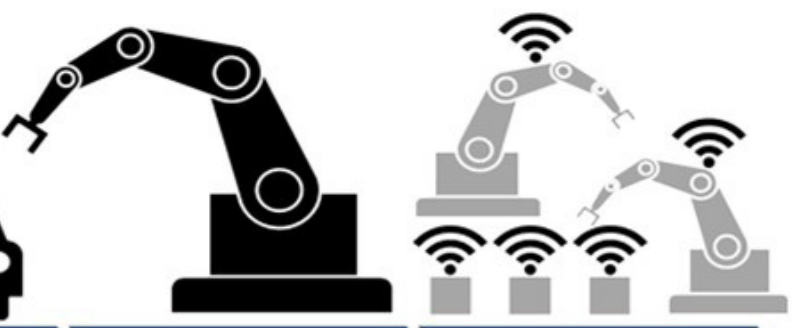

3rd

Computer and automation

1968 4th
Cyber Physical

Systems
2011-

Figure 1 - Periods of industrial revolutions.Source: By Christoph Roser at AllAboutLean.com under the free CC-BY-SA 4.0 license. ${ }^{8}$

which are: horizontal and vertical integration, and end-to-end engineering. The authors also describe these concepts: ${ }^{13}$

- Vertical integration: corresponds to the implementation of a manufacturing system with characteristics of flexibility and reconfigurability through the complete integration of hierarchical systems of the internal environment of the company;

- Horizontal integration: create collaborations between companies to provide an integrated ecosystem where physical, intellectual, energy and financial resources can flow between many different companies;

- End-to-end engineering: encompasses the first two and aims to create a powerful chain of software tools, which enables mass customization through product modeling at each stage in the value chain.

By embracing new technologies such as developments in advanced robotics, artificial intelligence, nanotechnology, 3D printing and Biotechnology, this environment will be marked by a widespread disruption not only in business models, but also in labor markets in the coming years, with huge changes anticipated in the skill sets needed to prosper. ${ }^{16}$ From then on, the main discussion that arises concerns the ways in which business, government and individuals will respond to these developments.

The future lies in the Fourth Industrial Revolution that depends on the integration of physical, digital and biological structures, sustained by the internet and the industrial value chain. ${ }^{12,17}$

\section{Understanding industry $\mathbf{4 . 0}$}

Industry 4.0 is the union of technologies applied to the production 
environment. Among them are internet of things (IoT), cyber-physical systems (CPS), 3D printing, big data, autonomous vehicles, automated systems, artificial intelligence and new materials. ${ }^{2}$

The fourth industrial generation presents as main characteristics: data interconnection, integration and innovation. ${ }^{18}$ Among the set of technologies are:

- Cloud computing: The delivery of faster and more flexible innovation services for data storage, including servers, software, database, analytics and intelligence over the internet ("the cloud"); 18

- Virtualization or digital twins (asset virtualization): Provides simulation of the process environment according to business requirements; ${ }^{19}$

- Internet of things (IoT): Makes possible to connect objects, transfer data without human intervention and interconnection between equipment through the internet in convergence with wireless technology; ${ }^{20}$

- Big data analytics: Due to the high volume, variety and speed of data generated by sensors and control systems, there is a need to collect, integrate, store, process and analyze data for Industry 4.0; ${ }^{21}$

- Cyber-physical systems (CPS): Complex systems that require specifications for the chronological control of processes, security modeling, rationalization of continuous events for mapping and sequencing in discrete events; 22

- Internet of services (IOS): Characterized by a large number of services supported by software distributed over the internet, requiring new standards and integration architectures, as well as flexible and dynamic mechanisms of data security; ${ }^{23}$

- Autonomous robots: Robots with autonomous capacity used in production lines to perform complex activities; ${ }^{18}$

- Vertical and horizontal integration: Key concepts for the implementation of the Industry 4.0.24 It integrates internal and intercompany activities in order to add value to the entire value chain;

- Cybersecurity: Consists of methods used to detect and prevent intruders. It represents the need to protect management systems and production lines with increasing connectivity; ${ }^{25}$

- Additive manufacturing or 3D printing: A manufacturing method that adds layer-by-layer material to produce an object. Industry 4.0 will enable the production of small custom batch volumes with the assistance of additive manufacturing. ${ }^{26}$

The Fourth Industrial Revolution will have major impacts on the economic scenario, such as consumption, GDP, employment, trade and inflation. ${ }^{2}$ It is estimated that Germany alone should invest annually $€$ 40 billion in Industry 4.0 by 2020, and that the figure could reach $€ 140$ billion annually across Europe. ${ }^{25}$ The United States should invest US\$ 1.35 trillion in the next 15 years. ${ }^{29}$

In the industry, the implementation of cyber-physical systems will enable large gains in efficiency and flexibility, and incredible gains in productivity throughout the production chain. ${ }^{13}$

However, the main impacts of Industry 4.0 will occur on employability, because there will be the need for people to improve their skills to deal with all new technologies; 2,28

According to a report issued by the World Economic Forum The Future of Jobs - Employment, Skills and Workforce Strategy for the Fourth Industrial Revolution, these impacts can lead to a cut of approximately 7.1 million jobs between 2015 and 2020 due to a series of redesigns that do and will take place from the factory floor. ${ }^{16}$
By introducing developments in artificial intelligence, robotics, new materials, 3D printing and Biotechnology, such an environment will be marked by "a widespread disruption not only in business models, but also in labor markets over the next five years, with huge changes anticipated in the skill sets needed to prosper". ${ }^{16}$ That is why this work shows the Biotechnology and the possible professions of the future.

\section{Advances in biotechnology}

Biotechnology started to be pointed out as a high priority science recently, however, some biotechnological processes have been used since antiquity. The use of Biotechnology began long before the beginning of the Christian era, with the fermentative processes obtained from microorganisms. These fermentative processes were possible to manufacture alcoholic beverages from cereal grains; the Egyptians also used the fermentation process for the production of bread. ${ }^{29}$

In 1876, Louis Pasteur proved that fermentation is caused by microorganisms and that each type of fermentation was produced by a microorganism. ${ }^{30}$

With the discovery of penicillin by Alexander Fleming in 1928, it made the production of antibiotics a major industrial milestone. During the Second World War, antibiotics became part of biotechnological industrial processes. ${ }^{30}$

Biotechnology in the first half of the 20th century was based on enzymes, with the main objective of improving the quality of food..$^{29}$ Another landmark of modern Biotechnology was the chemical synthesis of DNA (deoxyribonucleic acid) performed by Kornberg in 1967, a fact he called "genetic revolution". ${ }^{31}$

Modern Biotechnology has a wide scope, multidisciplinary character and is linked to many and different applications in various segments of activities, such as: mining, health, fermentation, agriculture and livestock. ${ }^{29}$

In mining, the Biotechnology professional works with the improvement of metal concentration processes for the use of ores, biolixiviation mineral bacterial, hydrometallurgy and others. ${ }^{30}$

In the area of health, the Biotechnology professional works in the production of metabolic regulating proteins, interferon, human insulin, growth hormones, neuroactive, peptides, and others. ${ }^{32}$ Still in the health area, we work in the production of vaccines with the objective of preventing several diseases. ${ }^{29}$

In agriculture, the Biotechnology professional develops research with genes, which have allowed the improvement of several cultures, such as coffee, sugar cane, soy, cotton, tomato, potato and many others. Other developments include the production of products for pest control, seed production, genetically modified foods. ${ }^{33}$

In livestock, the Biotechnology professional is present in the development of animal feeding, and in the control of reproduction that are available in embryo transfer techniques, such as artificial insemination, in vitro experiments, cloning, genetic mapping and molecular markers. ${ }^{34}$

Biotechnology is a powerful tool that can replace a large number of current processes in the near future and create innovative and sophisticated solutions to a wide range of problems.

Several developments that happened with the advances in Biotechnology can be cited: 33

- New biological therapies;

- Discovery of new energy sources based on biotechnological research;

- Structuring of analytical tools;

- Expansion of nanobiotechnology;

- Proliferation of transgenic technology;

- Development of tools in bioinformatics;

- Expansion of biomass to biofuel conversion technologies;

- Development of research based on sustainability; 
- Biotechnology law, intellectual property, patents and biotechnological ethics;

- The development of business models, processes and management of Biotechnology companies.

The multidisciplinary nature of Biotechnology has allowed researchers and professionals to seek new research and studies. According to studies by Deloitte consultancy, Biotechnology today represents about $27 \%$ of the global market, and the expectation is that by 2024 this number will increase to $31 \%$. $^{35,34}$

In Brazil, Biotechnology has increasingly acquired great importance in the economic and social sectors. One of the reasons is the population size, because the greater the number of inhabitants of a country, the greater the consumption of food, medicines, vaccines, among other products. ${ }^{34}$

\section{Biotechnology and industry 4.0}

What is understood by the integration of Biotechnology and the Industry 4.0 is the incorporation of digital systems and technologies (big data, IOT, cloud computing, advanced robotics, virtual simulation, artificial intelligence, 3D printing) to Biotechnology activities, in order to allow the integration of physical systems with virtual systems (cyber-physical systems). It has been used by large Biotechnology companies, and partly also by academic laboratories. But compared to manufacturing and service industries, Biotechnology needs to evolve in the automation of research laboratories for productivity and quality to improve exponentially. ${ }^{36}$

A fully-automated laboratory uses robots or other networked computer devices to monitor experiments and gather more accurate data. This would increase productivity, reproducibility and research accuracy. ${ }^{36}$

A recent research published by Nature indicates that Science is actually experiencing a crisis of reproducibility, as more than $70 \%$ of the 1576 researchers interviewed tried unsuccessfully to reproduce the experiences of another scientist, following the methodology described by the latter in books or articles. ${ }^{37}$ Another study published in Plos Biology estimated the amount of US\$ 28 billion in nonreproducible preclinical research in the US alone. ${ }^{38}$

Companies have developed laboratory automation with software and hardware, developing organizations for efficient production of compounds according to the customer's request. There are many companies where their genetic engineering steps are automated, including high-performance analysis. ${ }^{30}$

In the laboratory of the future, there will be autonomous communication of task execution processes, with automated process flows; and professionals for the design and implementation of these laboratories will be necessary, i.e., a new modality of work will be created. ${ }^{39}$

According to STEQ the German national innovation network aims to facilitate the integration between intelligent laboratories and Industry 4.0. The goal is to drive the development and standardization of innovative technologies, and the intended results "include simplified process flows, better quality, greater efficiency and greater process reliability". ${ }^{39}$

Another initiative in Germany in Stuttgart is the development of the Innovation Center for Laboratory Automation, with the aim of creating the intelligent laboratory of the future. This laboratory is already providing some initial impulses and generating many ideas, one of which is intelligent tracking, where it automatically documents and analyzes hand movements using 3D image analysis. The system accurately captures and records every step of the process, and consequently saves time, reduces workloads for employees and provides better results. ${ }^{39}$

In parallel to the initiatives developed in Germany, Japan is also developing a two-arm robot for use in pharmaceutical laboratories. The project leaders are the company Yaksawa and the National Institute of Advanced Industrial Science and Technology of Japan. The robot named
"Mahoro" can perform laboratory work and conduct crops more quickly, accurately and efficiently. As the robots have no immune system, they are particularly ideal for working with biological hazards, such as radioactive materials, and conducting clinical trials. ${ }^{40}$

In Austria, researchers at the University of Technology in Vienna recently used a high-resolution 3D printing process to produce live cells. The technology uses a special "biological ink" that allows the team to incorporate cells into a 3D matrix. ${ }^{41}$

According to the Brazilian Association of Bioinnovation (ABBI), innovative Biotechnology solutions also provide a vital contribution to the transition from current unsustainable economic practices to renewable industrial systems - the circular and bio-based economy - combining innovation and sustainability to solve major global challenges. The main benefits of these innovative solutions are:42

- Improved productivity and industrial competitiveness by $40 \%$, reducing the use of natural resources, fossil raw materials, and the number of processes;

- Accelerates the transition from a nonrenewable base industry to a circular, restorative and regenerative economy, avoiding emissions of up to 2.5 billion tons of $\mathrm{CO}_{2}$ per year;

- It contributes significantly to a food-secure and low-carbon future by reducing the amount of land needed to replace $10 \%$ of the world's gasoline with advanced biofuels by $60 \%$;

- It replaces traditional chemicals in food and beverage production, causing less impact on natural flavors and colors.

\section{The professions of the future}

Changes in labor markets have been driven by interconnected forces throughout the globalized world: technological advances and innovations, constant changes in organizations and the market, competition in local, national and international markets at the same time, and the need to sustainably manage waste disposal and energy use to avoid harmful climate change. These forces together are potentially driving significant changes in socioeconomic systems throughout the world. Trends that can be identified will shape the work of the future. Globalization, population aging, and social, technological and business trends will create opportunities for many professions, with names that often do not exist today. ${ }^{43}$

According to the UN, with the advancement of technology and the insertion of Industry 4.0, many impacts on employability will occur. ${ }^{44}$ Still according to the UN, in 2035 the global unemployment rate will reach $20 \%$ and by the middle of this century, $40 \%$ of jobs that exist today will cease to exist. ${ }^{44} \mathrm{~A}$ consultancy carried out by McKinsey shows that $50 \%$ of current jobs in Brazil could be automated, and about $60 \%$ of professions could have at least $30 \%$ of their activities automated. ${ }^{45}$

Schwab also identifies as the most prone professions to automation: telemarketing; insurance appraisers, executive secretary, receptionists, real estate agent, among others. That is, activities marked by a high degree of repetition of tasks and low complexity. Still according to the researcher, the professions with lower propensity for automation would be: mental health professionals, choreographers, doctors, psychologists, human resources managers. ${ }^{2}$

This dynamic, however, would be accompanied by a growing and significant work opportunity to be created, especially related to computing and mathematics, for analysts and data scientists, specialists in artificial intelligence and automation, marking a separation between humans, machines and algorithms, and their respective performances in the productive and social chain. It is also at this point that it is necessary to mention the discussion on the emergence of hybrid jobs, combining skills from previous functions in a new role. ${ }^{35}$

\section{The future of work - World Economic Forum}

In 2016, leading entrepreneurs and world leaders met at the World Economic Forum in Davos, Switzerland, to debate the future of the 


\section{G.J. Silva, A.C. Massabni}

economy and business worldwide. One theme has received special attention: the enormous revolution in the profile of professions in recent years and what to expect from the future of work in the coming decades. The report The Future of Jobs and Skills published by the World Economic Forum, interviewed entrepreneurs, human resources executives and professionals specialized in business strategy from 15 developed or developing regions or countries, including Brazil, United States, Germany, United Kingdom, France, Mexico and Persian Gulf countries. ${ }^{16}$

The mechanisms for changing the working environment envisaged by thestudyaremanyandall linkedtotheconceptofIndustry4.0. Figure2shows the main technologies that should drive changes in the future of work. ${ }^{16}$

It is possible to observe in Fig. 2 that the technological mechanisms that will transform the work environment are related to the cyberphysical systems, i.e., machines, robots and vehicles will be connected to the internet, and through a large data storage (big data) the artificial intelligence will control the decisions and actions to be taken, integrating the physical systems with the virtual ones.

The study also showed the demographic and socioeconomic factors of change in jobs according to the World Economic Forum, and are represented in Figure 3:16

The big change in jobs is also related to the work environment (technology insertion) and flexible working arrangements. Companies and employees need to adapt, as there are and there will be major changes in geographical barriers and greater consumer interest in ethical and privacy issues.

In Brazil, the drivers of change in work are identified in Figure 4 according to the World Economic Forum: ${ }^{16}$

- By 2020, there will be a drop of more than 7.1 million jobs due to changes in the market;

- Of these, 2/3 are concentrated in office functions and administrative areas.

An example of a job that should become obsolete is in the consumer service area - because of the growth in the use of mobile technology as a customer relationship channel.

On the other hand, there should be a gain of 2 million jobs in areas related to computing, mathematics, engineering, architecture and Biotechnology.

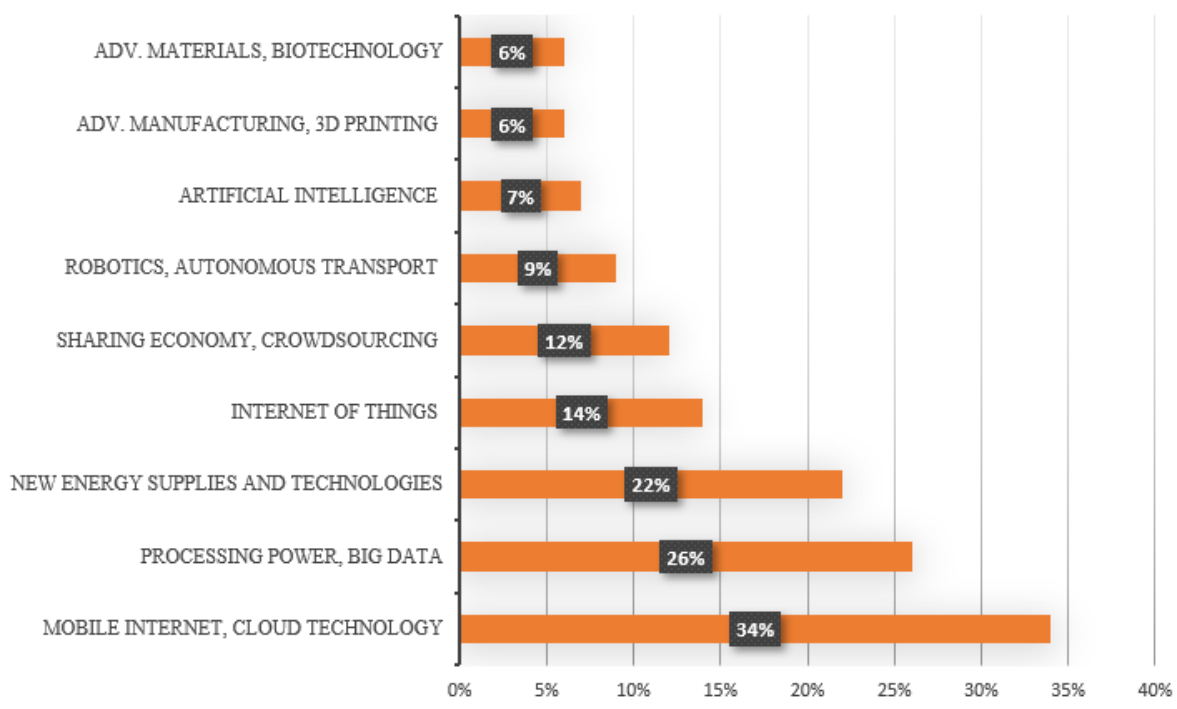

Figure 2 - Technologies that drive changes in the future of work. Source: Adapted from the Global Challenge Insight Report (World Economic Forum 2016)..$^{16}$

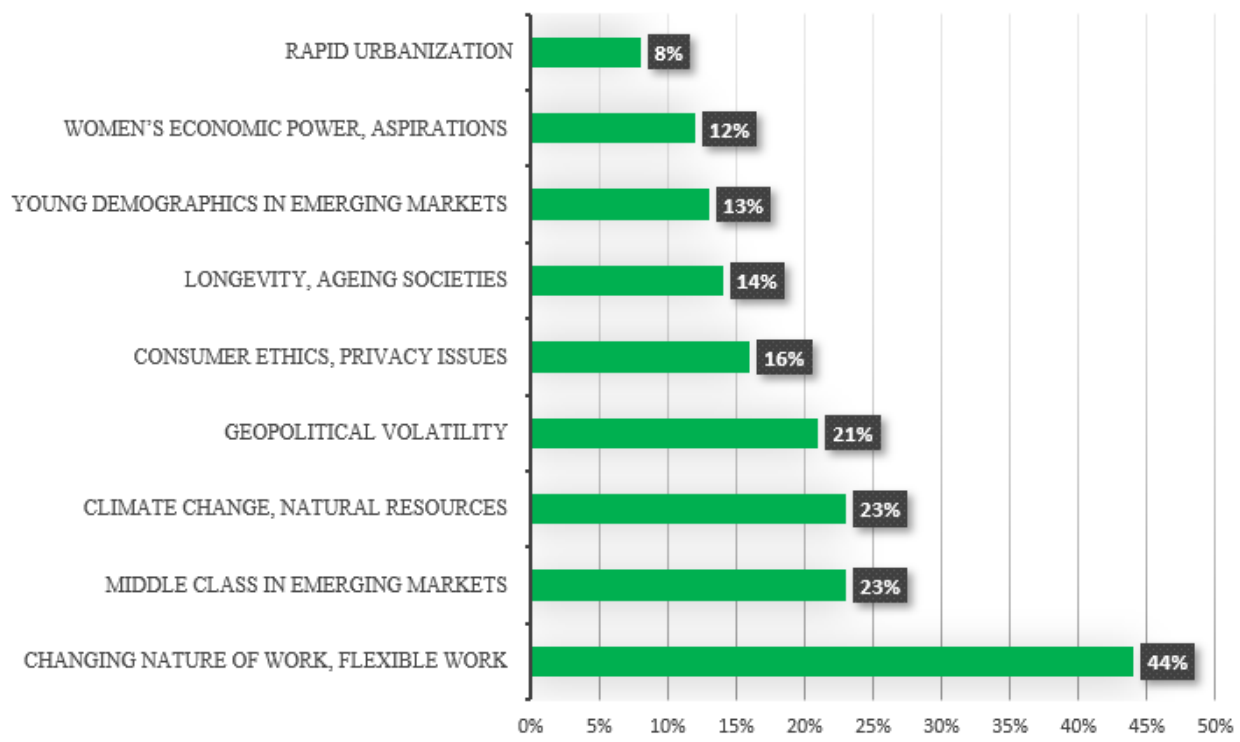

Figure 3 - Factors of changes in employment.Source: Adapted from the Global Challenge Insight Report (World Economic Forum 2016). ${ }^{16}$ 


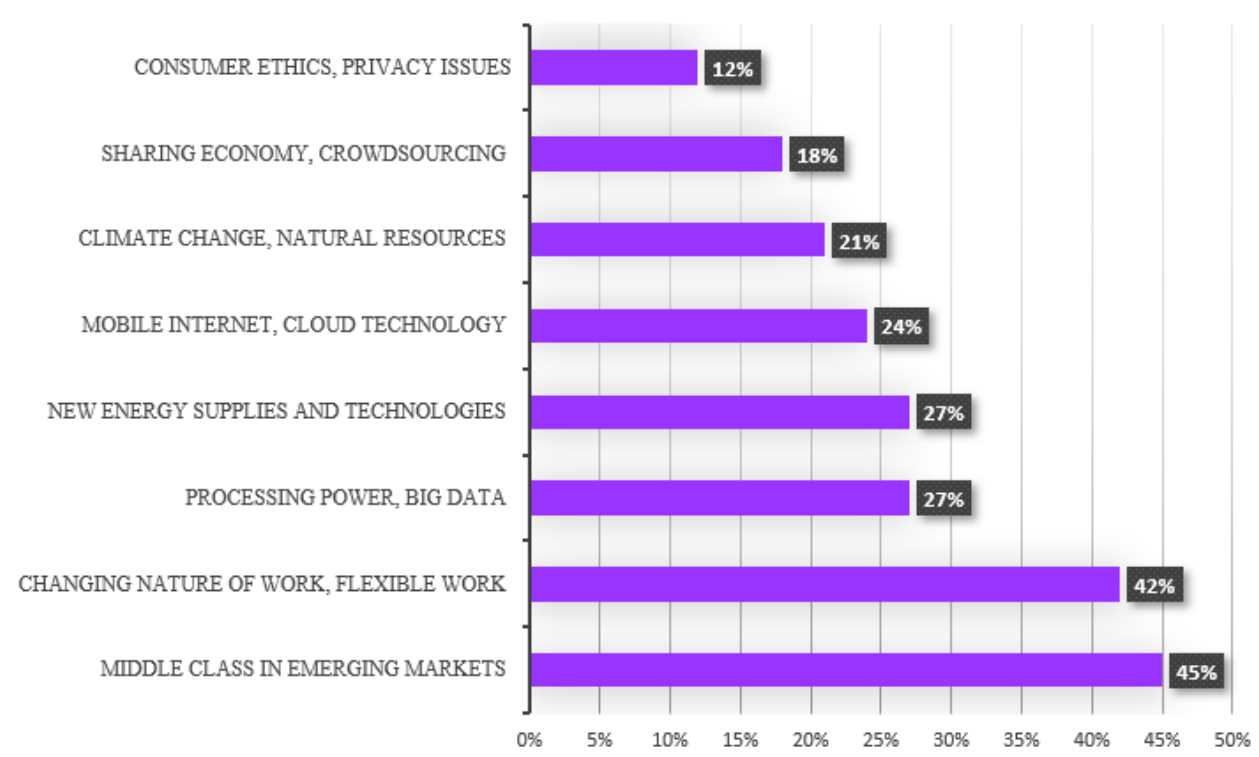

Figure 4 - Drivers of change in labor in Brazil. Source: Adapted from the Global Challenge Insight Report (World Economic Forum 2016). ${ }^{16}$

\section{The future of work - Por Luís Rasquilha}

According to Rasquilha, it is essential to know the innovations that are emerging in the market to know which path to follow and thus ensure professional success. Currently, the demand for professionals with skills in Industry 4.0 begins to emerge, and it tends to increase. The professional who is able to practice any of the professions of the future will be ahead of his peers, ensuring the best positions in the market and higher revenues. The reason is that, from the moment a certain occupation is valued, the search for professionals who are qualified to exercise it increases. ${ }^{46}$ Some occupations are listed below:

- Waste manager

- Environmental engineer

- Oil and gas engineer

- Hospital engineer

- Bioinformacionist

- Telemedicine technician

- Retirement adviser

- Quality of life manager

- Cloud specialist

- Big data manager

- Corporate lawyer

- Tax lawyer

- Uranium recycler

- Mechatronic engineer

- Personal robot mechanic

- Geomicrobiologist

- Experimental therapist

- Drone driver

- Personal food shopping advisor

- Productivity adviser showroom manager.

\section{The future of work in Biotechnology}

The study developed by the World Economic Forum presents Biotechnology as one of the main technologies driving the future of work, i.e., professionals in the field need to observe the changes and professionalize. ${ }^{16}$

The power of digitalization has enabled Biotechnology to develop new Biotechnology products and processes from the processing and understanding of genetic information of microorganisms. With the use of Industry 4.0 practices, the convergence of innovations will be intensified. ${ }^{47}$

Rasquilhaalso presents current and future possibilities of professions in the field of Biotechnology: ${ }^{46}$

- Quality control and material analysis: Use of the automated laboratories for high efficiency analysis, but for this it is necessary to build these laboratories needing professionals from Industry 4.0 and also from Biotechnology to support the new research;

- Regulatory affairs: Biotechnology also lacks professionals who can deal with documents, bureaucracy, deadlines from regulatory agencies, read and interpret legislation. Regulation of new transgenics and biopharmaceuticals. To operate in the application of the main regulatory laws in new biotechnological products or services in food, chemical, veterinary or pharmaceutical industries;

- Scientific consultant: To conduct consultancies for companies interested in performing or optimizing processes, for example DNA cloning and fermentation, or interested in interpreting genetic data. Their role is to transfer scientific knowledge about a particular medicine to physicians for everyday use;

- Waste management: The production of waste by industry in line with government policies generates demand for this type of service. The correct direction of waste and the transformation of waste into a source of income are the primary activities of professionals in this area.

- Environmental engineering: The concern with the impact on the environment, both in the civil construction sector and in the industrial sector makes professionals with knowledge in the environmental area necessary, since sustainability and the environment are pressing issues today and in the future.

- Bioinformation: It is a scientific area that works with genetic 
information bridging clinical techniques and drug development. It is a profession linked to innovation and also to the aging macro trend of the population.

- Telemedicine: The search for innovation and increased life expectancy of the population will highlight telemedicine professionals. It is a person who is part of a team that offers diagnosis and treatment for the inhabitants of more remote areas. An alternative to the lack of health professionals in more remote areas of Brazil, telemedicine allows people to have access to diagnosis without being in the same place as the medical team.

- Uranium recycling: Through sustainable techniques it converts uranium waste into energy that can be used for cities and infrastructures.

- Geomicrobiology: Bacteria and microorganisms have characteristics that can help in research in areas such as medicine, food or health and well-being, incorporating these microcharacteristics into everyday industry and research.

\section{Conclusions}

New technologies have impacted on employability, especially those related to process automation and information digitization, and have also influenced the relationship of the labor market and the new professions that will occupy the old and new functions.

According to the United Nations, the global unemployment rate in 2035 will reach $20 \%$ with the advancement of technology and the insertion of Industry 4.0, and by the middle of this century, $40 \%$ of the jobs that exist today will cease to exist. McKinsey showed that $50 \%$ of current jobs in Brazil could be automated, and about $60 \%$ of professions could have at least $30 \%$ of their activities automated. Some professions are more prone to automation: telemarketing, insurance assessors, executive secretary, receptionists, real estate agent, among others. ${ }^{2}$

In this scenario, there will be many challenges in the labor market, professionals will have to continuously develop skills and be attentive to the evolution of technologies that will generate demands for future professions.

Biotechnology is one of the driving technologies of the future of work, i.e., professionals working in this area need to observe changes and professionalize. The power of digitalization has enabled Biotechnology to develop new Biotechnology products and processes from the processing and understanding of genetic information of microorganisms.

Artificial intelligence, robotics, 3D printing are technologies that will impact Biotechnology on a large scale. In the future, it will be required the production of new drugs for health treatment, food with greater amount of protein and vitamins, cultivation of seeds with greater resistance to pests and climatic conditions, but for this to happen there will be a demand for professionals who can develop enabling technologies such as algorithms, software and hardware, with biology and Biotechnology knowledge.

The analysis leads to the conclusion that, with economic growth, Biotechnology innovation and sufficient investment, the creation of new jobs can counterbalance the impact of automation, even if some economies may need additional investment to reduce the risk of job scarcity. An even greater challenge will be to ensure that workers have the skills and support needed to complete the transition to new jobs. In this sense, it is necessary to invest in education, research and studies to develop and implement means for transition.

However, it must be recognized that this is a process of reflection, adaptation and innovation in education systems. In addition, the need for companies to work in collaboration with educational institutions and governments is reiterated, in order to find the necessary skills and abilities for the professionals of the future.

\section{Acknowledgements}

The authors thank Fundação Nacional de Desenvolvimento do Ensino Superior Particular (Funadesp) and Fundação de Amparo à Pesquisa do Estado de São Paulo (Fapesp) Grant n. 2017/11570-3 for financial support.

\section{References}

1. Powell WW, Koput KW, Smith-Doerr L. Interorganizational collaboration and the locus of innovation: Networks of learning in biotechnology. Adm Sci Q. 196;41(1):116-45. https://doi. org/10.2307/2393988

2. Schwab K. A Quarta Revolução Industrial. São Paulo: Edipro; 2016.

3. Sezer OB, Dogdu E, Ozbayoglu AM. Context-aware computing, learning, and big data in internet of things: a survey. IEEE Internet Things J. 2018;5(1):1-27. https://doi.org/10.1109/JIOT.2017.2773600

4. Trigueiro MGS. O clone de Prometeu: a biotecnologia no Brasil: uma abordagem para a avaliação. Brasília: Editora UnB; 2002.

5. Arbix G. Biotecnologia sem fronteiras. Novos Estud - CEBRAP. 2007;78:5-10. https://doi.org/10.1590/S010133002007000200001

6. Mendonça MAA, Freitas RE. Biotecnologia: Perfil dos grupos de pesquisa no Brasil, Texto para discussão, No. 1375 [Internet]. Brasília: Instituto de Pesquisa Econômica Aplicada (IPEA); 2008. [cited 2019 Nov. 08]. Available at: https://www.econstor.eu/bitstream/10419/91004/1/597623287.pdf

7. Batalha MO, Bonacelli MB, Silva VMM, Borras MA, Saito J, Jôlo F. Pós- Graduação e Biotecnologia: formação e capacitação de recursos humanos no Brasil. In: Silveira JMFJ, Dal Poz ME, Assad AL. (org) Biotecnologia e recursos genéticos: desafios e oportunidades para o Brasil. Campinas: UNICAMP, Instituto de Economia (FINEP); 2004.

8. All About Lean. Industry 4.0 - what works, what doesn't [Internet]. 2017 [cited 2019 Nov. 08]. Available at: https://www.allaboutlean. com/industry-4-0-potentials/

9. Jones SE. Against technology: from the Luddites to neo-Luddism. Abingdon: Routledge; 2006.

10. Stearns PN. Consumerism in world history: The global transformation of desire. Abingdon: Routledge; 2006. https://doi. org/10.4324/9780203969885

11. Chandrasekhar CP, Ghosh J, Roychowdhury A. The 'demographic dividend' and young India's economic future. Econ Political Wkly. 2006;41(49):5055-64.

12. Hermann M, Pentek T, Otto B. Design principles for industrie 4.0 scenarios. In: 2016 49th Hawaii International Conference on System Sciences (HICSS). Koloa: IEEE; 2016. https://doi.org/10.1109/ HICSS.2016.488

13. Kagermann H, Wahlster W, Helbig J. Securing the future of German manufacturing industry Recommendations for implementing the strategic initiative INDUSTRIE 4.0 Final report of the Industrie 4.0 Working Group. Washington: National Academy of Science and Engineering; 2013 [cited 2019 Oct. 07]. Available at: https://en.acatech.de/wp-content/uploads/sites/6/2018/03/Final_report_Industrie_4.0_accessible.pdf 
14. Zhou K, Liu T, Zhou L. Industry 4.0: Towards future industrial opportunities and challenges. In: 2015 12th International Conference on Fuzzy Systems and Knowledge Discovery (FSKD). Zhangjiajie: IEEE; 2016. https://doi.org/10.1109/FSKD.2015.7382284

15. Qin J, Liu Y, Grosvenor RA. Categorical framework of manufacturing for Industry 4.0 and beyond. Procedia CIRP. 2016;52:173-8. https:// doi.org/10.1016/j.procir.2016.08.005

16. World Economic Forum. The future of jobs employment, skills and workforce strategy for the fourth industrial revolution [Internet]. 2016 [cited 2019 Oct. 10]. Available at: http://www3.weforum.org/docs/ WEF_Future_of_Jobs.pdf

17. Peters MA. Technological unemployment: educating for the Fourth Industrial Revolution. Educ Philos Theory. 2016;49(1):1-6. https:// doi.org/10.1080/00131857.2016.1177412

18. Chen Y, Du Z, García-Acosta M. Robot as a service in cloud computing. In: 2010 Fifth IEEE International Symposium on Service Oriented System Engineering. Nanjing: IEEE; 2010. https://doi.org/10.1109/ SOSE.2010.44

19. Lu Y, Xu X. Resource virtualization: a core technology for developing cyber-physical production systems. J Manuf Syst. 2018;47:128-40. https://doi.org/10.1016/j.jmsy.2018.05.003

20. Pujara SM, Satyanarayana KV. Internet of things and libraries. Ann Lib Inf Stu. 2015;62:186-90.

21. Santos MY, Sá JO, Andrade C, Lima FV, Costa E, Costa C, et al. A big data system supporting Bosch Braga Industry 4.0 strategy. Int J Inf Manage. 2017;37(6):750-60. https://doi.org/10.1016/j.ijinfomgt.2017.07.012

22. Xu B, Zhang LA. Clock based framework for specifying and modeling the time constraints of cyber physical systems. In: 2013 IEEE 11th International Conference on Dependable, Autonomic and Secure Computing. Chengdu: IEEE; 2014. https://doi.org/10.1109/ DASC. 2013.77

23. Autili M, Giannakopoulou D, Tivoli M. Thematic series on verification and composition for the internet of services and things. J Internet Serv Appl. 2018;9(10):1-3. https://doi.org/10.1186/s13174-0180080-9

24. Wang S, Wan J, Li D, Zhang C. Implementing smart factory of Industry 4.0: an outlook. Int J Distrib Sens N. 2016;12(1):1-10. https:// doi.org/10.1155/2016/3159805

25. Kemmerer RA, Vigna G. Internet security and intrusion detection. In: Proceedings of the 25th International Conference on Software Engineering (ICSE 03). IEEE Computer Society, 2003.

26. Vayre B, Vignat F, Villeneuve F. Designing for additive manufacturing. Procedia CIRP. 2012;3:632-7. https://doi.org/10.1016/j.procir.2012.07.108

27. Buhr D. Social innovation policy for Industry 4.0. Bonn: Friedrich-Ebert-Stiftung; 2017.

28. Hecklau F, Galeitzke M, Flachs S, Kohl H. Holistic approach for human resource management in Industry 4.0. Procedia CIRP. 2016;54:16. https://doi.org/10.1016/j.procir.2016.05.102
29. Lima N, Mota M. Biotecnologia. Fundamentos e aplicações. Portugal: Lidel; 2003.

30. Borzani W, Schmidell Netto W, Lima UA, Aquarone E. Biotecnologia industrial: Fundamentos. São Paulo: Edgard Bucher; 2001.

31. Scriban R. Biotecnologia. São Paulo: Manole; 1985.

32. Rifkin J. O século da biotecnologia. São Paulo: Makron Books; 1999.

33. Fulekar MH. Nanotechnology: Importance and Applications. New Delhi: I K International Publishing House; 2010.

34. Malajovich MA. Biotecnologia. Rio de Janeiro: Axcel Books do Brasil; 2004.

35. Deloitte. 2019 Global life sciences outlook Focus and transform | Accelerating change in life sciences [Internet]. 2019 [cited 2019 Oct. 10]. Available at: https://www2.deloitte.com/content/dam/Deloitte/ global/Documents/Life-Sciences-Health-Care/gx-Ishc-Is-outlook-2019.pdf

36. National Academies of Sciences, Engineering, and Medicine; Division on Earth and Life Studies; Board on Chemical Sciences and Technology; Board on Agriculture and Natural Resources; Board on Life Sciences; Committee on Future Biotechnology Products and Opportunities to Enhance Capabilities of the Biotechnology Regulatory System. Preparing for Future Products of Biotechnology. Washington: National Academies Press; 2017. https://doi.org/10.17226/24605

37. Baker M. 1,500 scientists lift the lid on reproducibility. Nature. 2016;533(7604):452-4. https://doi.org/10.1038/533452a

38. Freedman LP, Cockburn IM, Simcoe TS. The economics of reproducibility in preclinical research. Plos Biology. 2015;16(4):1-9. https:// doi.org/10.1371/journal.pbio.1002165

39. STEQ. Laboratório 4.0 - Integrado e Inteligente: este é o laboratório do futuro [Internet]. 2018 [cited 2019 Oct. 25]. Available at: http:// www.steq.com.br/blog/laboratorio-4-0-integrado-e-inteligente-este-e-o-laboratorio-do-futuro/

40. The birth of "Mahoro": turning to the idea of a multipurpose twoarmed robot. AIST Today [Internet]. 2015. p. 21-22. [cited 2019 Oct. 14]. Available at: https://www.aist.go.jp/Portals/0/resource_images/ aist_e/aist_today/2015_55/pdf/2015_55_p16_p28.pdf

41. Ligon SC, Liska R, Stampfl J, Gurr M, Mülhaupt R. Polymers for $3 \mathrm{D}$ printing and customized additive manufacturing. Chem Rev. 2017;117(15):10212-90. https://doi.org/10.1021/acs.chemrev.7b00074

42. Dias RF, Carvalho CAA. Bioeconomia no Brasil e no mundo: panorama atual e perspectivas. Rev. Virtual Quim. 2017;9(1):410-30. https://doi.org/10.21577/1984-6835.20170023

43. Challenger JA. Working in the future: How today's trends are shaping tomorrow's jobs; globalization, aging, and trends in technology and society will create opportunities for eco-relations managers, retirement consultants, and outsourcing coordinators. The Futurist. 2005;39(6):47-50.

44. Organização das Nações Unidas (ONU). Transformando nosso mundo: A agenda 2030 para o desenvolvimento sustentável [Internet]. 2016 [cited 2019 Oct. 15]. Available at: https://nacoesunidas.org/ 


\section{G.J. Silva, A.C. Massabni}

pos2015/agenda2030/

45. Manyika J, Lund S, Chui M, Bughin J, Woetzel J, Batra P, et al. Jobs lost, jobs gained: workforce transitions in a time of automation. New York: McKinsey \& Company; 2017. [cited 2019 Oct. 20]. Available at: $\quad$ https://www.mckinsey.com/ /media/McKinsey/Featured\%20 Insights/Future\%20of\%200rganizations/What\%20the\%20future\%20of\%20work\%20will\%20mean\%20for\%20jobs\%20skills\%20 and\%20wages/MGI-Jobs-Lost-Jobs-Gained-Report-December-6-2017.ashx]

46. Rasquilha L, Franco M. Viagem ao futuro: a verdade sobre a prospectiva e o foresight. São Paulo: Actual; 2015.

47. Ustundag A, Cevikcan E. Industry 4.0: Managing the digital transformation. Cham: Springer; 2018. https://doi.org/10.1007/978-3319-57870-5 